\section{Silver Spring monkeys}

SIR - As one who attended both State of Maryland vs. Edward Taub trials and served on the search and seizure warrant team that removed documents and animals from Taub's laboratory, I wish to comment on S. B. Galsworthy's letter (Nature 349, 13; 1991).

Galsworthy writes that "Taub was never convicted". Indeed, he was - by a circuit court judge and then, in a later trial de novo, by a district court jury. His convictions were for violations of Article 27, Section 59 et seq. of the Annotated Code of the State of Maryland, otherwise referred to by law enforcement personnel as "the anti-cruelty statute".

I saw inside Taub's laboratory. The place was abominably filthy, its rusted cages with their broken bars failed to meet federal minimum standards (a matter of public record), all medications had long expired (as shown in the police photographs admitted into evidence), and animals languished with infected wounds (as confirmed in the testimony of primatologist Dr Geza Teleki and four veterinarians with expertise in primate medicine who personally examined the Silver Spring monkeys).

Taub's conduct should be used as an example of how not to do things in the laboratory.

\section{People for the Ethical \\ Treatment of Animals, \\ PO Box 42516 , \\ Washington, \\ DC 20015-0516, USA}

- Taub's conviction on one count of the original indictment was overturned on appeal and the remaining 118 counts dismissed - Editor, Nature.

\section{The parasites}

$\mathrm{S}_{\mathrm{IR}}-$ Efficient scientific work is increasingly dependent on the rapid availability of laboratory reagents. During the past few years, I have as a routine been placing orders by telefax from remote Finland directly to US dealers and obtained the needed items by express delivery within 2-3 days.

Oncogene Science (Manhasset, New York) responded to my recent order for monoclonal antibodies by advising me to contact its new local distributor in Sweden. When I did so, it turned out that the distributor did not keep the antibodies in stock but had to order them as well.

In a second telefax, I made this clear to Oncogene Science, asking it to avoid further delay of a stopover in Sweden by shipping the antibodies directly to Helsinki. In spite of this, the antibodies were delivered through the distributor in Sweden. The consequence was a delay of an additional week and a doubling of the price.

It is reasonable that distributors, who keep local stocks of reagents and provide a rapid service, should charge extra to compensate for their costs. But middlemen who add 100 per cent or more to the price only for changing the address labels on the packages and causing delay are not acceptable. They are just parasites in the scientific community and should be eradicated.

Department of Pathology,

Leif C. Andersson

University of Helsinki,

SF-00290 Helsinki,

Finland

\title{
The collective farm song
}

\section{K0JX03HA II 3AIIEBKA}

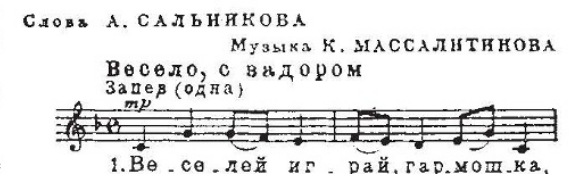

1. Ве - сө лей иг - рай, гар.мот.ка,
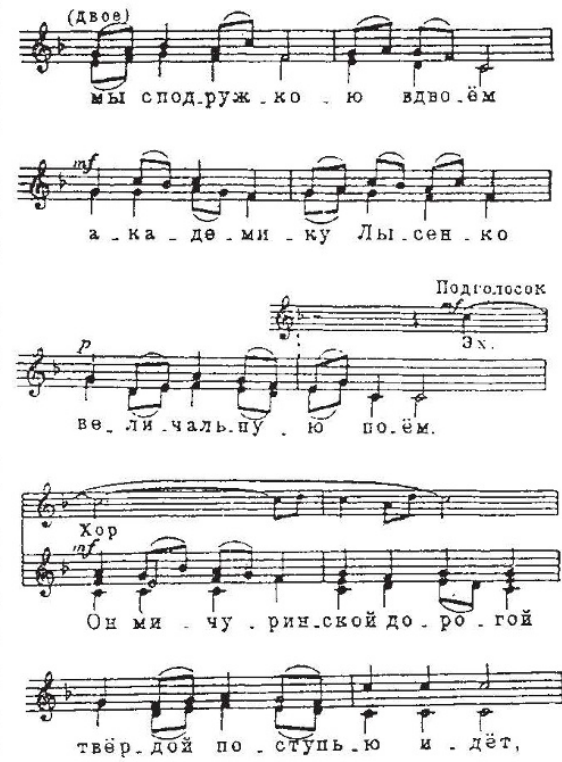

1. To the accompaniment of the accordion My friend and I sing in honour

Of Academician Lysenko*

He follows Michurin's path

With his unerring step

And is not fooled by the followers

of Morgan and Weismann

\section{Long-awaited Spring}

Has come into our lives

So have fertile fields

That are unafraid of bad weather

Thanks to his teachings

We reap and gather the crop

We have banned bad weather from our fields By working hard on them

THE document reproduced above, a song on the glories of lysenkoism for peasant parties on collective farms, is further evidence to add to that demonstrating the strength of the malign grip exercised by the biologist T. D. Lysenko on Soviet agriculture earlier this century. At the top is the music and the four verses in Russian with a translation by Barbara Izdebska below. The song was unearthed by Dr Yuri F. Bog-

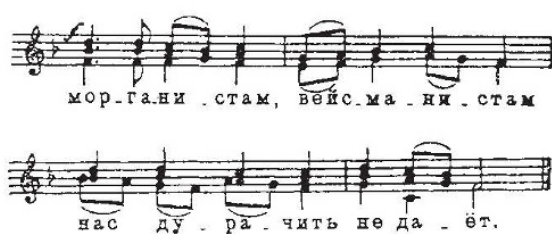

2. В нашей жизни наступнла Долгожданная весна: Стала нивам плодородным Непогода ні страшна. Мы давно уж по науке Урожай в полях растим. Мы к земле прнложим рукя, Недороды запретим.

3. Академнком Лысенко Bсе колхозннки горды. Он во всех краях Отчнзны Учит нас растить сады. Перестранвать прнроду Нам в стране своей прншлось Чтоб советскому народу Благодатнее жнлось.

\author{
4. Веселей играй, гармошка, \\ Mы с подружкою вдвосе \\ Академнку Лысенко \\ Величальную поё. \\ Он мичурннской дорогой \\ Твёрдой поступью ндёт, \\ Морганистам, вейсманистам \\ Нас дурачить не даёт.
}

3. Every member of collective farms Is proud of Academician Lysenko He teaches the whole country How to cultivate gardens

And so there is a 'perestroika' in nature Across the whole country which will fructify life of the Soviet nation

4. To the accompaniment of the accordion My friend and I sing in honour Of Academician Lysenko

He follows the path of Michurin With his unerring step

And is not fooled by the followers Of Morgan and Weismann

danov of the Vavilov Institute in Moscow, and sent on to Nature by Professor J. H. Edwards, Genetics Laboratory, Department of Biochemistry, University of Oxford OX1 3QU, UK. Photocopies of the original in full are available from Professor Edwards.

Editor, Nature

* Lysenko (1898-1976), Soviet biologist, who had a damaging influence on Soviet biology..." (The Macmillan Concise Encyclopaedia). 